hospital. At the beginning of the war in 1939 he was called up into the Army, but soon afterwards was taken prisoner by the Soviet Army and sent to one of the prisoner-of-war camps of the Katyn group. Dr Haber was lucky to survive the slaughter of the Polish officers. In 1941, when released from the prison camp, he joined the Polish Army which was then being formed in Russia; the Polish Division left Russia in 1942 to join up with the 8th British Army and Haber took part in the African and Italian campaigns.

After the war Arthur Haber came to Britain with the Polish Division and subsequently settled in North London, where he practised with great success as a general practitioner, bringing considerable skill to those committed to his care. His courtly manner, the warmth and charm of his personality, and his kindly good will made him popular with patients and colleagues, and he had many friends. Blessed with a happy marriage, he found great joy in the company of his wife, Zosia, whose devotion and encouragement played an important part in his professional success. He is greatly missed by all who knew him.-EZ, AB.

\section{O MOSES}

MD, LRCP, LRCS, LRFPS

Dr O Moses, who was in general practice at Hammersmith, died peacefully at his home on 28 December. He was 80.

Otto Moses was born in Germany in 1900 and qualified in medicine at the University

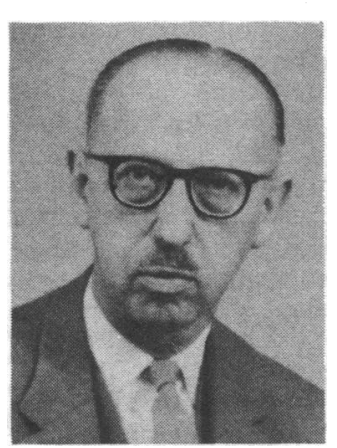
of Cologne in 1923. In 1933 political events compelled him to leave Germany and to start anew in this "isle of civil and religious liberty." He took the Scottish diploma in 1935 and set up in practice at Hammersmith in 1936. His sad experience in Hitler's Germany

contributed to the gravitas, compassion, and dignity that he brought to his profession. A sound practitioner of integrity he conducted a busy practice in West London for 44 years, being regarded not only as a conscientious physician but also as a friend. Nothing was too much trouble for him, and many were his acts of kindness and love.

Otto Moses had a flair for languages and, despite professional commitments, he enjoyed translating foreign medical publications and was a fellow of the Institute of Linguists. Also interested in the welfare of his colleagues, he was considered to be the doyen of Hammersmith general practitioners and represented them on the local medical committee for some 25 years. He also served with distinction as chairman of the Kensington and Hammersmith Division from 1960 to 1962 , and on reorganisation of the National Health Service he was chosen to serve on his district management team.

At medical meetings Dr Moses's observations were treated with respect for he spoke with authority based on his wide experience. His tall dignified figure will be sadly missed. $\mathrm{He}$ is survived by his wife, whose support and companionship made her a pillar of strength to him, by a son-who is also a doctor-and by his grandchildren.-LC.

\section{E W GRAHAME}

MD, CHM, FRCS, FRCSED

Mr E W Grahame, who was medical superintendent and surgeon at Middlesbrough General Hospital, died last year.

Ernest Wells Grahame came from southwest Scotland, the birthplace of many distinguished medical men, and graduated at Glasgow in 1926. After spending some time in general practice he decided to concentrate on surgery and on becoming highly qualified worked in Surrey before being appointed in 1947 as medical superintendent and surgeon at the Middlesbrough General Hospital, where he worked for the rest of his career. Times were difficult, war-time shortages and problems persisted, and the imminence of the National Health Service created uncertainty, but Grahame worked with great determination and energy to build up a modern hospital and a first-class surgical service.

Ernest Grahame performed a vast amount of routine and emergency surgery, and wrote up his experiences of liver injuries as well as providing valuable data for discussion on the association of the blood groups and peptic ulcer. In the interests of his patients he never minded courting unpopularity and was always ready to stand up to politicians and bureaucrats with a well-prepared case, but to his patients and colleagues he was considerate, loyal, and helpful.

After retiring Ernest Grahame turned for a while to his other love-farming-but his last years were saddened by the crippling illness of his wife, whom he nursed with great devotion and who died not long before him. They had no children.-BW.

\section{H MORGAN WILLIAMS $M B$, FRCS}

Mr H Morgan Williams, who was formerly senior consultant surgeon at Poole Hospital, died on 16 December at the age of 72.

Hugh Morgan Williams was born at Shrewsbury on 10 September 1908 and spent his boyhood in South Africa, returning to England to be educated at Bedford School. He studied medicine at St Bartholomew's Hospital, London, where he graduated in 1933 and took his FRCS a year later. For the next five years he was in general practice at Parkstone, but at the outbreak of war returned to surgery and in 1946 was appointed honorary consultant surgeon at the Poole Cornelia Hospital. From 1949 to 1965 Hugh was honorary secretary of the medical advisory committee of the Bournemouth and East Dorset hospital group, becoming its chairman. For 15 years he was chairman of the medical staff committee of Poole Hospital, and also served on the Bournemouth and East Dorset Hospital management committee for 16 years and on the Wessex Regional Hospital Board for four. During the final years of his busy professional life Hugh Morgan Williams played an outstanding part in the complete rebuilding of Poole Hospital, which was opened by the Queen in 1969.

Hugh had two other interests that gave him immense pleasure: for 23 years he was an active and valued governor of Canford School; and he was a representative of the Church
Assembly and newer Synod, often speaking on medicosocial problems.

Precise and careful about detail, Hugh was also humorous and cheerful-firm over essentials, but generous about non-essentials -and he had a gift for drawing people together into effective harmonious co-operation. What gave his life direction and purpose was his strong Christian faith. For many years he was an influential Christian leader in the Bournemouth area, where he led a successful Crusader class at Parkstone and was a welcome speaker on specialist subjects at youth groups. Many of us in the medical profession will remember Hugh for his active part in the early development of the Christian Medical Fellowship. An efficient and witty local secretary of the Bournemouth conferences that attracted around 200 doctors and their wives for many years, he will be greatly missed by all who knew him.

Hugh Morgan Williams is survived by his devoted wife, Sue, and by a son and three daughters by his first wife, Jean.-DMJ.

\section{AMY M FLEMING}

DSC, MD, FRCOG

DRC writes: I had the honour and good fortune to have Miss Fleming (obituary, 24 January, p 328) as my chief from 1939 until 1942 at yet another of the London hospitals with which she was associatedLewisham. I thought that I knew her well, but because of her modesty had no idea of her international reputation. Until recently she kept in touch with my wife and me and in one letter expressed amused astonishment that she should have been invited to make a lecture tour in North America. In an expansive moment she once hinted that she had met an influential male chauvinist, a fellow consultant at one of the hospitals that she graced, who had not endeared himself to her.

During the blitz we had one particularly noisy night. After her ward round the next day I asked Miss Fleming how she and her sister had fared. With her pleasant Scottish accent she answered: "We were quite all right-you see we had piled up columns of books at the window in case of blast, and what's more they were German books."

\section{H A D SMALL}

$M B, C H B$, FRCS

AG writes: It was a privilege to have known "Joe" Small (obituary, 31 January, p 394) during his student days in New Zealand and later as a colleague. He was a friendly, sporting type who took risks and overcame them by application. Large in body, heart, and spirit, he was a powerful surgeon, colleague, and contributing committee man whose inner loyalty and kindness will long be remembered by patients, friends, and countrymen.

\section{Correction}

\section{P J MOIR}

We regret that we were in error in the obituary of Professor Moir (31 January, p 395) in that we said that he was a house surgeon at Glasgow: in fact, he was house surgeon to Sir Berkeley Moynihan in the General Infirmary at Leeds. 